\title{
POTRET PERGESERAN MAKNA BUDAYA MA'NENE DI KECAMATAN BARUPPU KABUPATEN TORAJA UTARA PROVINSI SULAWESI SELATAN
}

\author{
Yusri, dan Mardianto Barumbun \\ Lembaga Penelitian Mahasiswa (LPM) Penalaran \\ Universitas Negeri Makassar, Makassar 90222, Indonesia \\ E-mail : Yusryaldianocrew@yahoo.com
}

\begin{abstract}
ABSTRAK Tujuan dari penelitian ini ialah untuk mengetahui pergeseran makna yang terjadi pada budaya Ma'nene masyarakat Baruppu. Penelitian ini merupakan penelitian kualitatif dengan menggunakan pendekatan etnografi, peneliti berusaha mencari makna yang ada di balik simbol- simbol yang digunakan dalam upacara Ma'nene. Sampel sumber data dipilih secara purposive dan bersifat snowball sampling. Teknik pengumpulan data yang digunakan yaitu observasi, wawancara dan dokumentasi. Analisis data dalam penelitian kualitatif dilakukan sejak sebelum memasuki lapangan, selama di lapangan dan setelah selesai di lapangan. Pergeseran makna yang terjadi dalam ritual ini disebabkan karena pola pikir masyarakat setempat yang menganggap bahwa penyelenggaraan upacara adat ini hanya sekedar meneruskan budaya leluhur tanpa melihat kemurnian akan tujuan awal upacara adat itu diselenggarakan yakni sebagai wujud penghormatan dan kepedulian kepada leluhur. Hal tersebut terlihat dari penambahan atau pun pengurangan simbol-simbol yang terdapat dalam ritual Ma'nene. Rasionalitas, faktor ekonomi, dan budaya instan merupakan faktor penyebab pergeseran pola pikir masyarakat Baruppu.
\end{abstract}

Kata Kunci : Budaya, Ma’nene dan Sulawesi Selatan

\section{PORTRAIT MA'NENE CULTURAL SHIFT IN THE MEANING OF SUB-REGENCIES BARUPPU TORAJA NORTHERN PROVINCE OF SOUTH SULAWESI}

ABSTRACT The purpose of this study was to determine the meaning shifts that occur in society Baruppu Ma'nene culture. This study is a qualitative study using ethnographic approaches, researchers tried to find the meaning that lies behind the symbols used in the ceremony Ma'nene. Sample data sources are selected purposively and snowball sampling. Data collection techniques used were observation, interview and documentation. Data analysis in qualitative research conducted since before entering the field, on the field during and after completion in the field. Meaning shifts that occurred in this ritual due to the local community mindset that considers that implementation of this ceremony just continue ancestral culture without seeing initial purity of purpose that held the ceremony as a form of respect and concern for the ancestors. It is seen from the addition or subtraction of symbols contained in the ritual Ma'nene. Rationality, economic and cultural factors are the causes instant public mindset shift Baruppu

Key Words : culture, Ma'nene and South Sulawesi

\section{PENDAHULUAN}

Indonesia merupakan integrasi berbagai golongan etnis, komunitas agama dan kepercayaan lokaL, maka tidak heran Indonesia memiliki identitas kebudayaan yang sangat kental dan tersebar di setiap suku yang ada di Indonesia. Kepercayaan masyarakat yang hidup dan berkembang di setiap etnis, suku, marga dan desa merupakan kebudayaan lokal yang dapat memberikan dan mencerminkan ciri bagi daerah setempat. Sebagai salah satu unsur kebudayaan lokal, kepercayaan masyarakat dapat menjadi perekat bagi terwujudnya Negara Kesatuan Republik Indonesia (Rasyid, dkk, 2004). Setiap suku yang ada di Indonesia tentunya sampai sekarang masih memperlihatkan eksistensi kebudayaannya dalam artian adat istiadat yang mereka yakini. Namun, tidak sedikit juga suku yang sampai sekarang sudah tidak lagi mempertahankan adat istiadatnya. Mereka secara perlahan-lahan mulai bernegosiasi dengan perkembangan era modernitas sekarang. Komunitas adat masyarakat Baruppu yang terletak di Kabupaten Toraja Utara Provinsi Sulawesi Selatan merupakan komunitas yang menekuni budaya Ma'nene secara mendalam. Budaya ini merupakan salah satu peninggalan nenek moyang yang harus mereka lestarikan. Budaya Ma'nene yang rutin diadakan oleh masyarakat Baruppu ini setiap tahunnya penuh dengan simbol- simbol yang menitipkan suatu pesan atau makna yang mendalam yang tentunya diwariskan oleh para leluhur mereka. 
Upacara Ma'nene merupakan sebuah upacara mengganti busana jenazah leluhur. Pada saat Ma'nene berlangsung, peti-peti mati para leluhur, dikeluarkan dari makammakam dan liang batu, kemudian diletakkan di tempat upacara. Pada saat yang sama, sanak keluarga dan para kerabat sudah menunggu dan berkumpul. Kemudian dengan hati-hati, wakil dari keluarga mengeluarkan jenazah dari peti dan kemudian mereka memasangkan pakaian yang berupa kain baru ke tubuh mayat. Upacara Ma'nene yang dilaksanakan masyarakat Baruppu dianggap sebagai wujud kecintaan mereka pada para leluhur, tokoh dan kerabat yang sudah meninggal dunia. Mereka tetap berharap, arwah leluhur menjaga mereka dari segala gangguan jahat, hama tanaman dan juga kesialan hidup.

Dari hasil observasi yang telah dilakukan oleh peneliti bahwa pelaksanaan Budaya Ma'nene ini sudah tidak sesuai lagi dengan konteks awal dari pelaksanaan budaya tersebut. Terdapat beberapa simbol dalam budaya tersebut yang mulai disesuaikan dengan konteks era sekarang. Melalui hal tersebut maka kiranya penting untuk melakukan penelitian lebih mendalam bagaimana pergeseran makna budaya Ma'nene tersebut.

Setelah melakukan pengkajian terhadap simbol-simbol yang digunakan dalam upacara Ma'nene dengan menggunakan metode ilmiah, nantinya kita akan mengetahui apakah ada pergeseran makna atau pun penambahan simbol yang terjadi dalam upacara Ma'nene ini. Penambahan simbol-simbol baru dalam upacara tersebut mengindikasikan bahwa upacara tersebut sudah mengalami pergeseran makna dari fungsi aslinya. Pergeseran makna atau pun penambahan simbol yang terjadi pada upacara Ma'nene ini sering kali dipengaruhi oleh pola pikir masyarakat setempat yang berubah yang semula berpola pikir tradisional berubah menjadi pola pikir modern.

Beranjak dari permasalahan yang telah dipaparkan di atas maka judul penelitian yang diangkat oleh peneliti ialah " Potret Pergeseran Makna Budaya Ma'nene di Kecamatan Baruppu Kabupaten Toraja Utara Provinsi Sulawesi Selata”.

\section{Budaya}

Kata kebudayaan berasal dari bahasa Sansekerta "buddhayyah" yaitu bentuk jamak dari kata "buddhi" yang berarti budi atau akal. Sehingga kebudayaan dapat diartikan sebagai hal- hal yang berhubungan dengan akal (Koentjaraningrat, 2002). Sedangkan dalam bahasa Inggris, budaya berasal dari kata culture dan dalam bahasa Belanda diistilahkan dengan cultuur. Adapun dari bahasa Latin berasal dari kata colera yang berarti mengolah, mengerjakan, menyuburkan, mengembangkan tanah. Selanjutnya defenisi ini mengalami perkembangan yaitu segala daya dan aktivitas manusia untuk mengolah dan mengubah alam (Setiadi, 2007).

Menurut Koentjaraningrat dalam Abdulkadir (2005) kebudayaan memiliki 3 wujud diantaranya adalah sebagai berikut :

a. Keseluruhan ide gagasan nilai norma peraturan dan sebagainya yang berfungsi mengatur, mengendalikan, dan member arah pada kelakukan dan perbuatan manusia dalam masyarakat yang disebut adat tata kelakuan.

b. Keseluruhan aktivitas berpola dari manusia dalam masyarakat yang disebut sistem sosial. Sistem sosial terdiri dari rangkaian aktivitas manusia dalam masyarakat yang selalu mengikuti pola- pola tertentu berdasarkan adat tata kelakuan.

c. Benda- benda hasil karya manusia yang disebut kebudayaan fisik

Dari beberapa pengertian budaya tersebut peneliti menuliskan bahwa segala yang berasal dari akal adalah sebuah kebudayaan. Budayamerupakankeseluruhan perbuatan dan hasil karya manusia yang melekat pada diri setiap manusia yang diperoleh dengan cara belajar. Budaya dalam masyarakat tentunya akan mengalami yang namanya perkembangan dan tentunya memerlukan proses belajar untuk mengalami perkembangan tersebut.

Untuk menafsirkan sebuah makna yang terkandung dalam kebudayaaan, maka hal paling utama yang harus diketahui adalah bagaimana cara menangkap atau pun menginterpretasikan simbol-simbol 
atau pun tanda-tanda yang terdapat dalam kebudayaan tersebut. Menurut Geertz dalam Mulder (2001) manusia mempunyai kaitan yang erat dengan kebudayaan.

C. Kluckhon dan W.H. Kelly mengatakan bahwa kebudayaan adalah pola hidup yang tercipta yang terdapat pada setiap waktu sebagai pedoman tingkah laku manusia. Sedangkan menurut E.B Taylor kebudayaan adalah suatu kesatuan jalinan kompleks yang meliputi pengetahuan, kepercayaan, kesenian, susila, hukum, adat istiadat, dan kesanggupan-kesanggupan lain yang diperoleh seorang sebagai anggota masyarakat (Fatonah dkk, 2003).

Menurut James P. Spardley dalam Sobur (2003), semua makna budaya diciptakan dengan menggunakan simbolsimbol. Dari beberapa pendapat sudut pandang yang digunakan oleh peneliti dalam hal ini bahwa kebudayaan tersusun dari simbol-simbol atau pun tanda-tanda yang mencerminkan makna dari kebudayaan tersebut. Penggunaan simbol dalam wujud sebuah kebudayaan dilaksanakan dengan penuh kesadaran, pemahaman dan penghayatan yang tinggi, dan dianut oleh setiap generasi.

\section{Budaya Ma'nene}

Ma'nene merupakan upacara mengenang keluarga yang telah meninggal sebagai bentuk rasa terima kasih dan penghargaan kepada mendiang atas jasanya bagi keturunan yang telah ditinggalkan dengan mengangkat mayat dari liang yang disebut Tunuan (kuburan batu masyarakat Baruppu) dan melapisi pakaian atau membungkus mayat tersebut dengan kain baru. Upacara ini merupakan kewajiban bagi masyarakat Baruppu yang dilaksanakan setiap tahunnya sepanjang bulan Agustus mulai dari tanggal 1 hingga 31 pada bulan tersebut.

Sebuah peringatan keras bagi masyarakat Baruppu atau pun wisatawan yang datang agar tidak mendekati lokasi pekuburan sebelum dan sesudah upacara Ma'nene dalam bulan Agustus. Lokasi pekuburan hanya dapat dikunjungi hanya pada pada saat upacara Ma'nene sepanjang bulan Agustus. Pengecualian jika ada masyarakat yang meninggal pada saat itu dan harus dibawa mayatnya ke area pekuburan. Adapun dampak apabila lokasi pekuburan dikunjungi sebelum atau setelah bulan Agustus, maka masyarakat setempat akan merasakan tanamannya diserang hama yang berdampak merosotnya hasil panen. Bahkan masyarakat di Baruppu percaya akan terjadi bencana besar yang akan melanda mereka.

\section{METODE}

Penelitian ini merupakan penelitian kualitatif dengan menggunakan pendekatan etnografi. Adapun lokasi penelitian ini adalah Kecamatan Baruppu Kabupaten Toraja Utara Provinsi Sulawesi Selatan. Dalam penelitian ini, subjek penelitian data dipilih secara purposive dan bersifat snowball sampling.

Adapun teknik pengumpulan data yang digunakan dalam penelitian ini adalah seperti observasi, wawancara, dan dokumentasi. Analisis data dalam penelitian ini dilakukan sejak sebelum memasuki lapangan, selama di lapangan, dan setelah selesai di lapangan . Peneliti menggunakan uji kredibilitas dalam melakukan pengujian keabsahan data yang meliputi beberapa tahap diantaranya seperti trianggulasi, menggunakan bahan referensi dan member check.

\section{HASIL DAN PEMBAHASAN}

Setelah melakukan peninjauan ilmiah dengan menggunakan metodologi yang sistematis, peneliti menemukan fakta-fakta di lapangan yang menjadi gambaran objektif mengenai simbol-simbol atau pun tanda-tanda yang ada dalam pelaksanaan ritual Ma'nene.

Adapun simbol-simbol dalam penyelenggaraan upacara Ma'nene ini seperti kain, binatang ternak (kerbau, babi, ayam), nasi, sesajian (pisang, ubi parut, rokok, snack dan minuman), pondok, tempat pelaksanaan ritual Ma'nene, jadwal pelaksanaan ritual Ma'nene, prosesi pelaksanaan dan nilai sakralitas dari budaya itu sendiri.

Selanjutnya akan dibahas satu per satu mengenai makna dari simbol-simbol tersebut dan apakah ada pergeseran makna yang terjadi terhadap simbol-simbol yang digunakan dalam ritual tersebut tentunya dengan membandingkan bagaimana pelaksanaan 
ritual Ma'nene terdahulu dan bagaimana pelaksanaan ritual Ma'nene sekarang.

\section{a. Kain}

Kain merupakan salah satu simbol terpenting dalam pelaksanaan ritual Ma'nene, sebab nantinya mayat yang telah dikeluarkan dari liang yang disebut Tunuan (kuburan batu masyarakat Baruppu) akan dibungkus dengan kain tanpa membuka kain yang telah melekat di tubuh mayat. Masyarakat Baruppu terdahulu tidak mempersoalkan jenis kain yang digunakan dalam pelaksanaan ritual Ma'nene sedangkan masyarakat Baruppu sekarang dalam pelaksanaan ritual Ma'nene mereka menggunakan jenis kain yang berbeda, mereka meyakini bahwa semakin tinggi derajat keluarga yang melakukan ritual Ma'nene maka semakin mahal pula jenis kain yang harus mereka gunakan untuk membungkus sang mayat.

\section{b. Nasi}

Nasi boleh dikatakan sebagai simbol tambahan dalam pelaksanaan ritual ini, sebab masyarakat Baruppu terdahulu tidak menggunakan nasi dalam pelaksaan ritual Ma'nene. Mereka meyakini bahwa nasi merupakan salah satu pantangan yang tidak boleh dibawa di sekitar area perkuburan atau pun area pelaksanaan ritual Ma'nene. Alasannya yaitu mereka beranggapan bahwa nasi adalah makanan dewa, jadi makanan dewa tidak boleh dibawa di tempat perkuburan yang merupakan tempat roh- roh atau pun arwah-arwah para leluhur mereka. Sehingga masyarakat Baruppu terdahulu menggunakan ubi parut sebagai pengganti nasi. Namun pelaksanaan ritual Ma'nene sekarang nasi merupakan simbol pelengkap. Selain ubi parut masyarakat juga membawa nasi yang nantinya untuk dikonsumsi di sekitar area perkuburan. Namun sebagai prasyarat nasi tidak boleh masuk di dalam area pelaksanaan ritual Ma'nene, sehingga masyarakat biasanya mengonsumsi nasi tetap di sekitar area perkuburan namun di luar area pelaksanaan ritual ini.

\section{c. Sesajian}

Sesajian yang digunakan dalam pelaksanaan ritual Ma'nene ini ialah seperti rokok, snack, gorengan, ubi parut, minuman, ayam, babi atau pun kerbau. Sesajian yang digunakan oleh masyarakat Baruppu sekarang dengan yang digunakan oleh masyarakat Baruppu terdahulu tidak mengalami yang namanya perubahan. Namun yang menjadi perbedaan adalah kepada siapa sesajian tersebut ditujukan. Masyarakat Baruppu terdahulu yang masih beragama Aluk Tudolo menganggap bahwa sesajian yang mereka bawa merupakan persembahan dari mereka untuk leluhur mereka. Mereka meyakini bahwa sesajian yang mereka bawa nantinya akan dicicipi oleh leluhur mereka, sehingga sesajian tersebut tidak boleh dicicipi oleh keluarga atau pun masyarakat yang melakukan ritual ini. Hal tersebut bertentangan dengan apa yang dilakukan oleh masyarakat Baruppu sekarang. Sesajian yang mereka bawa bukan mereka persembahkan untuk leluhur mereka namun sesajian tersebut untuk dikonsumsi oleh masyarakat dan keluarga yang melakukan ritual Ma'nene di area pekuburan. Perbedaan ini disebabkan karena masyarakat Baruppu sekarang sudah tidak ada lagi yang beragama Aluk Tudolo, mereka mayoritas beragama katolik atau pun protestan.

\section{d. Pondok}

Bagi masyarakat Baruppu terdahulu pondok merupakan salah satu simbol yang harus ada dalam pelaksanaan ritual Ma'nene ini. Mereka harus membangun pondok-pondok di sekitar area perkuburan dan nantinya mereka menginap satu malam di pondok tersebut. Tujuannya yaitu agar mereka bisa menemani semalaman para leluhur mereka, hal tersebut juga merupakan salah satu tanda kecintaan dan kepedulian mereka terhadap leluhur mereka. Namun masyarakat Baruppu sekarang tidak menjadikan lagi pondok sebagai salah satu simbol dalam pelaksanaan ritual Ma'nene, mereka hanya cukup membalut kain ke tubuh mayat tanpa harus menemani mayat tersebut semalaman.

\section{e. Tempat Pelaksanaan Ritual Ma'nene}

Salah satu simbol atau pun unsur terpenting dalam ritual Ma'nene ialah tempat pelaksanaan ritual tersebut. Ritual ini dilaksanakan di area pekuburan. Masyarakat tidak boleh memasuki area pekuburan 
sebelum tiba waktunya pelaksanaan ritual Ma'nene yakni bulan Agustus, terkecuali jika ada mayat yang diantar ke kuburan sebelum atau pun setelah bulan Agusutus. Masyarakat Baruppu meyakini bahwa orang yang telah mati dan orang yang masih hidup mempunyai tempat yang berbeda. Orang yang telah mati tempatnya di pekuburan dan orang yang masih hidup tempatnya di luar pekuburan, mereka memberikan batas antara dunia para leluhur mereka dan dunia mereka sendiri. Sehingga sebuah larangan besar memasuki area pekuburan sebelum bulan Agusutus. Adapun yang menjadi pembeda antara tempat pelaksanaan ritual Ma'nene sekarang dengan ritual Ma'nene masyarakat Baruppu terdahulu yaitu seluruh acara ritual Ma'nene wajib dilaksanakan di area pekuburan mulai dari pembungkusan mayat sampai penyambutan tamu. Sedangkan masyarakat Baruppu sekarang melaksanakan ritual ini di dua tempat, setelah proses pembungkusan mayat di area pekuburan selesai mereka melanjutkan acaranya di rumah masing-masing seperti acara makanmakan atau pun penyambutan tamu. Selain itu bagi masyarakat Baruppu dahulu sebuah larangan besar membawa nasi di tempat area pekuburan sebab seperti yang telah dipaparkan sebelumnya bahwa mereka meyakini bahwa nasi merupakan makanan dewa dan tidak boleh dibawa di area ritual Ma'nene. Namun bagi masyarakat Baruppu sekarang, mereka boleh membawa nasi di tempat ritual Ma'nene atau pun di area pekuburan namun tetap di luar batas yang telah mereka tentukan. Batasnya yaitu sungai yang mengelilingi area pekuburan, sehingga, mereka tidak boleh membawa nasi melewati sungai tersebut.

\section{f. Jadwal Pelaksanaan Ritual Ma'nene}

Salah satu hal menarik dalam penyelenggaraan ritual Ma'nene ialah mengenai jadwal pelaksanaan ritual tersebut. Ritual ini hanya dilakukan pada bulan Agusutus, mulai tanggal 1 Agustus sampai dengan 31 Agustus. Ritual ini dilaksanakan pada bulan Agustus sebab berdasarkan sejarah ritual Ma'nene, Pong Rumanden harus melakukan ritual ini setelah musim panen berlalu tepatnya pada bulan Agustus, sehingga sebuah pantangan besar melaksanakan ritual Ma'nene sebelum atau pun setelah bulan Agusutus. Namun masyarakat Baruppu sekarang, mereka mengenal yang namanya "Curi Waktu" yaitu mencuri waktu satu atau pun dua hari setelah bulan Agustus. Berdasarkan dari hasil wawancara dengan narasumber bahwa sebagian masyarakat Baruppu telah melakukan hal tersebut, dikarenakan mereka harus menunggu saudara mereka berkumpul sebelum melaksanakan ritual Ma'nene

\section{g. Prosesi Pelaksanaan}

Salah satu perbedaan antara ritual Ma'nene masyarakat Baruppu terdahulu dengan masyarakat Baruppu sekarang yaitu dilihat dari aspek tata cara pelaksanaannya. Prosesi pelaksanaan ritual Ma'nene sekarang terlihat lebih mudah dan lebih cepat dibandingkan dengan ritual Ma'nene masyarakat Baruppu terdahulu. Dahulu masyarakat melaksanakan ritual Ma'nene selama 5 sampai 6 hari. Hari pertama mereka ke kuburan untuk melihat keadaan makam, setelah mengadakan panen padi memasuki bulan Agusutus. Hari kedua mereka kembali ke kuburan untuk membersihkan makam. Pada hari ketiga mereka membuat pondokpondok di sekitar area pekuburan untuk tempat mereka menginap pada malam kelima, selanjutnya pada hari keempat mayat diturunkan dari liang dan acara puncak Ma'nene pun dimulai pada hari tersebut. Terakhir pada hari kelima mayat kembali dinaikkan di liang kuburan. Sedangkan prosesi pelaksanaan ritual Ma'nene sekarang terserah dari keluarga saja. Mereka ingin melaksanakan berhari- hari atau pun tidak tergantung dari kesepakatan keluarga, namun mayoritas masyarakat sekarang mengadakan Ma'nene selama 3 hari saja. Setelah mayat dibungkus dengan kain, acara dilanjutkan di rumah keluarga, bukan di makam lagi. Selain itu masyarakat sekarang tidak lagi menginap atau pun bermalam di area pekuburan menemani mayat selama satu malam beda dengan masyarakat Baruppu terdahulu. 


\section{h. Hewan Ternak}

Hewan ternak merupakan salah satu simbol yang ada dalam pelaksanaan ritual Ma'nene. Hewan ternak yang dimaksud dalam hal ini seperti babi, kerbau atau pun ayam. Masyarakat Baruppu terdahulu menjadikan simbol ini sebagai persembahan mereka untuk leluhur mereka, mereka menyembelih hewan ternak tersebut atas nama leluhur mereka. Sedangkan masyarakat Baruppu sekarang menjadikan simbol tersebut hanya sebagai simbol pelengkap, tergantung dari kemampuan keluarga yang melakukan ritual Ma'nene. Selain itu mereka mnyembeli hewan ternak bukan sebagai persembahan mereka untuk leluhur mereka namun nantinya sebagai lauk yang mereka konsumsi setelah prosesi Ma'nene di area pekuburan. Perbedaan ini disebabkan karena faktor agama. Masyarakat terdahulu melaksanakan ritual ini sesuai konteks Aluk Tudolo,sedangkan masyarakat Baruppu sekarang yang mayoritas beragama Katolik dan Protestan melaksanakan ritual tersebut sesuai dengan konteks agama mereka masing-masing.

\section{i. Nilai Sakralitas}

Ritual Budaya Ma'nene telah mengalami pergeseran makna kesakralan, hal tersebut telihat dari perbandingan pelaksanaan ritual ini antara masyarakat Baruppu dahulu dan sekarang. Masyarakat Baruppu dahulu melaksanakan ritual ini berpangkal sebagai pelestarian amanat leluhur dan sebagai pengukuhan nilai-nilai budaya yang berlaku turun temurun secara simbolik. Sedangkan masyarakat Baruppu sekarang lebih mendominasi melaksanakan ritual ini hanya semata untuk meneruskan tradisi. Selain itu antusiasme masyarakat untuk melaksanakan ritual ini sekarang mulai berkurang. Dulunya, ritual ini wajib untuk dilakukan oleh setiap masyarakat secara rutin setiap tahunnya, namun sekarang pola pikir masyarakat mulai berubah, mereka melaksanakan ritual ini bergantung dari kesepakatan keluarga dan bergantung dari dana yang mereka miliki. Kadang kala mereka melaksanakan ritual ini hanya sekali dalam tiga tahun, namun ada juga masyarakat yang melaksanakan ritual ini setiap tahunnya. Selain itu ritual ini yang dulunya dijadikan sebagai pelestarian amanat leluhur, sekarang sudah mulai dijadikan sebagai objek wisata Kecamatan Barupu. Hal ini terlihat dari pencanangan yang telah dilakukan oleh kepala desa di Kecamatan Baruppu ke pemerintah kota Toraja Utara.Dari semua problematika yang telah dipaparkan di atas, peneliti menemukan sebuah garis relasional yang sangat mendukung adanya pergeseren makna yang terjadi dalam ritual Budaya Ma'nene masyarakat Baruppu ditinjau dari hasil analisis terhadap simbol-simbol yang digunakan dalam ritual tersebut. Pergeseran makna yang terjadi dalam ritual ini disebabkan karena pola pikir masyarakat setempat yang menganggap bahwa penyelenggaraan upacara adat ini hanya sekedar meneruskan budaya leluhur saja tanpa melihat kemurnian akan tujuan awal upacara adat itu diselenggarakan yakni sebagai wujud penghormatan dan kepedulian kepada leluhur. Selain itu pemerintah setempat mulai mengemas sedemikian rupa ritual Ma'nene ini yang nantinya akan dipromosikan untuk kepentingan pariwisata. Kesakralan ritual Ma'nene seolah- olah luntur karena adanya pergeseran jaman serta pola pikir masyarakat . Hal tersebut terlihat dari penambahan simbol-simbol atau pun pengurangan simbol- simbol yang terdapat dalam ritual Ma'nene. Rasionalitas, kemudahan budaya instan, dan faktor ekonomi merupakan kesatuan yang dijadikan sebagai awal dari pemahaman masyarakat tersebut.

\section{SIMPULAN}

Setelah melakukan proses analisis terhadap simbol-simbol yang digunakan dalam budaya Ma'nene di Kecamatan Baruppu Kabupaten Toraja Utara Provinsi Sulawesi Selatan, maka peneliti dapat menyimpulkan bahwa budaya Ma'nene yang merupakan sebuah ritual atau pun prosesi upacara sebagai wujud penghormatan kepada orang tua atau pun leluhur yang telah meninggal telah mengalami pergeseran makna. Pergeseran makna yang terjadi dalam ritual ini disebabkan karena pola pikir 
masyarakat setempat yang menganggap bahwa penyelenggaraan upacara adat ini hanya sekedar meneruskan budaya leluhur saja tanpa melihat kemurnian akan tujuan awal upacara adat itu diselenggarakan.

Sebagai tindak lanjut dari penelitian ini agar dapat bermanfaat secara maksimal, maka peneliti menyarankan kepada beberapa pihak diantaranya bagi masyarakat agar kiranya dapat menjaga kemurnian akan tujuan awal suatu budaya khususnya budaya Ma'nene diselenggarakan.

Bagi pemerintah, agar kiranya dapat memberikan perhatian yang lebih dalam menjaga eksistensi nilai-nilai kebudayaan lokal yang merupakan identitas dari Negara Indonesia. Bagi institusi independen dalam bidang budaya, agar kiranya dapat lebih mengembangkan penelitian-penelitian yang bersifat kebudayaan secara lebih komprehensif dan terarah. Bagi peneliti, agar kiranya dapat mengemabangkan penelitian yang bersifat kebudayaan.

\section{DAFTAR PUSTAKA}

Abdulkadir, Muhammad. 2005. Ilmu Sosial Budaya Dasar. Bandung: Citra Aditya Bakti.

Fatonah, dkk. 2003. Bahan Ajar KLB semi que V: Jurusan Ilmu Komunikasi.

Koentjaraningrat. 2002. Pengantar Ilmu Antropologi. Jakarta: Rineka Cipta.

Mulder. Niels. 2001. Mistisme Jawa. Yogyakarta: Lkis

Setiadi , Elly M . 2007. Ilmu Sosial dan Budaya Dasar. Jakarta: Prenada Media.

Sobur, Alex. 2004. Semiotika Komunikasi. Bandung: Remaja Rosdakarya

Mulder. Niels. 2001. Mistisme Jawa. Yogyakarta: Lkis 